\title{
Obesity-Associated Lymphedematous Mucinosis: Two Further Cases and Review of the Literature
}

\author{
Caterina Ferrelia Anna Luisa Pinna ${ }^{a}$ Luca Pilloni $^{b} \quad$ Marialuisa Corbeddu ${ }^{a}$ \\ Franco Rongiolettia \\ aSection of Dermatology, Department of Medical Science and Public Health, University of

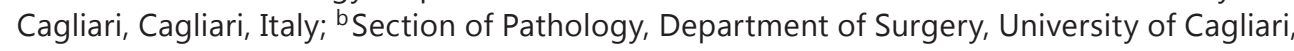 \\ Cagliari, Italy
}

Keywords

Lymphedema · Mucin · Obesity

\section{Abstract}

Cutaneous mucinoses are a group of conditions characterized by increased amounts of acid mucin in the dermis. They can be generalized or localized and occur isolated or in the setting of systemic diseases. Obesity-associated lymphedematous mucinosis is a distinct variant of mucinosis occurring in obese patients without any thyroid dysfunction. So far, only few cases of this rare condition have been reported in the English literature. Here, we describe two new cases and discuss some histological differences with the pretibial myxedema.

\author{
(c) 2018 The Author(s) \\ Published by S. Karger AG, Basel
}

\section{Introduction}

Obesity-associated lymphedematous mucinosis (OALM) is a rare and newly recognized disorder that can clinically mimic pretibial myxedema $[1,2]$. The absence of thyroid disease and histological findings can differentiate the two conditions [1].

\section{Report of Cases}

A 76-year-old obese, diabetic woman with a long history of hypertension came to our department for the presence of slowly growing asymptomatic papular lesions on both legs. She had a history of prolonged swelling of the lower extremities and referred the lesions 
1

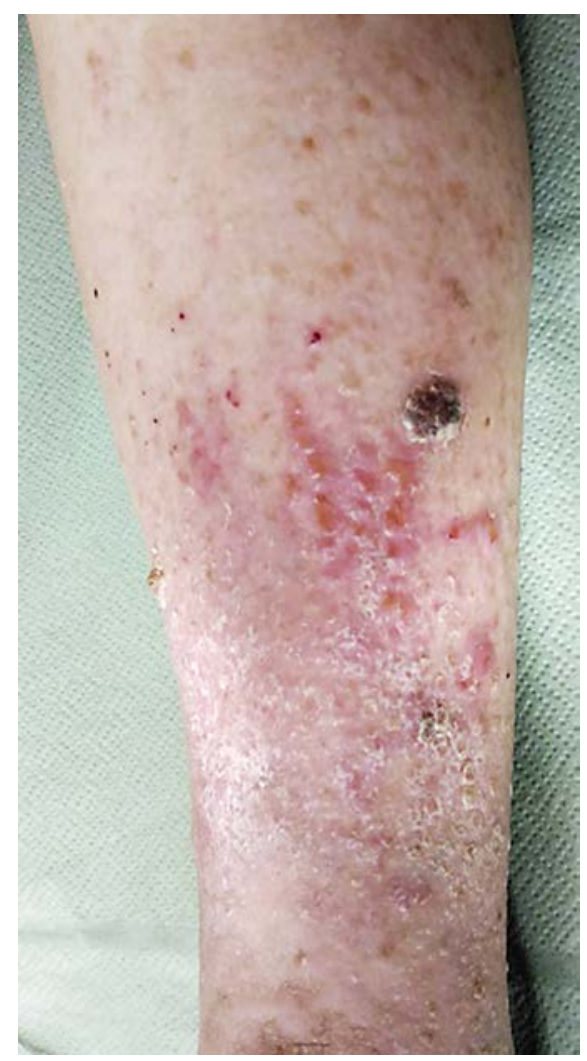

2

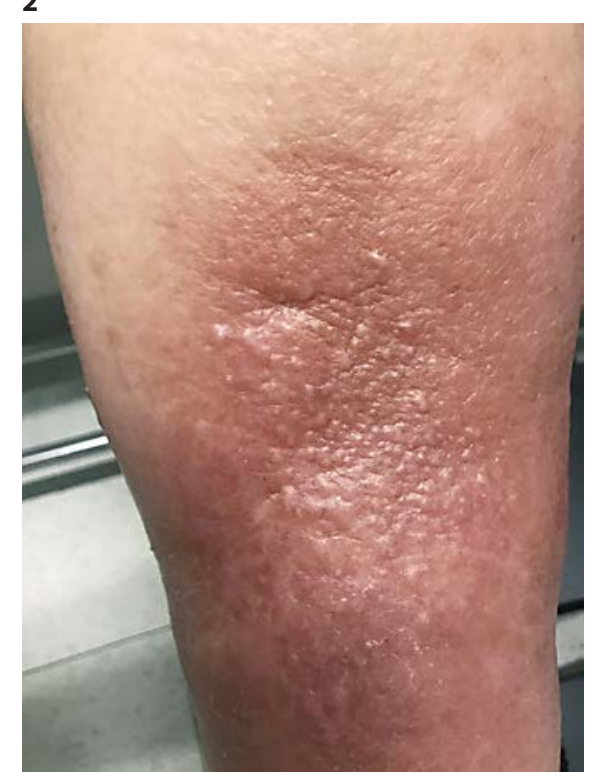

Fig. 1. Patient 1: translucent erythematous, skin-colored papulo-nodular lesions on the shins of edematous legs.

Fig. 2. Patient 2: semi-translucent, papulo-nodular lesion on an edematous, reddish background.

firstly had appeared over her right leg and subsequently involved the left leg. On dermatological examination, skin-colored to red, densely grouped, papulo-nodular lesions were present on both legs, affecting mainly the pretibial region. Some of them were translucent with a yellowish hue, others light brownish in color and bigger in size, with crust covering superficial erosion. A pitting edema was present on both legs (Fig. 1). No signs of venous insufficiency were present.

The second patient was a 72-year-old woman presenting with swelling and erythema on both her legs for 1 year. She had been overweight for 20 years (height $159 \mathrm{~cm}$, weight $98 \mathrm{~kg}$, and body mass index 38.7 [class II obesity]). On physical examination, reddish, semi-translucent papulo-nodules on both edematous legs were present (Fig. 2). Moreover, the patient had chronic heart failure, hypercholesterolemia, arterial hypertension, and type II diabetes mellitus. Venous duplex ultrasonography did not reveal an evident venous insufficiency. No therapy was given and she was lost to follow-up.

A skin biopsy, taken form a papular lesion on the leg of both patients, gave the same histopathological results, i.e., epidermal atrophy, dermal edema, angioplasia with thick-walled vertically running dermal vessels embedded in a fibromyxoid matrix. Prominent stellate fibroblasts and a discrete perivascular lymphocytic infiltrate were present. The Alcian Blue $\mathrm{pH} 2.5$ histochemical staining confirmed the presence of mucin in the superficial dermis (Fig. 3, Fig. 4).

Pretibial mucin deposition is a phenomenon that occurs in association with thyroid diseases (pretibial myxedema) or without any thyroid dysfunction (pretibial mucinosis) [1]. OALM represent a type of pretibial mucinosis, strongly associated with obesity, characterized by skin-colored to erythematous-yellowish semi-translucent papules, plaques and nodules, arising in an edematous lymphostatic skin of the lower legs, especially on the shins [1]. 
Fig. 3. H\&E. Epidermal atrophy, mucinous edema of the upper part of dermis with increased stellate fibroblasts (inset).
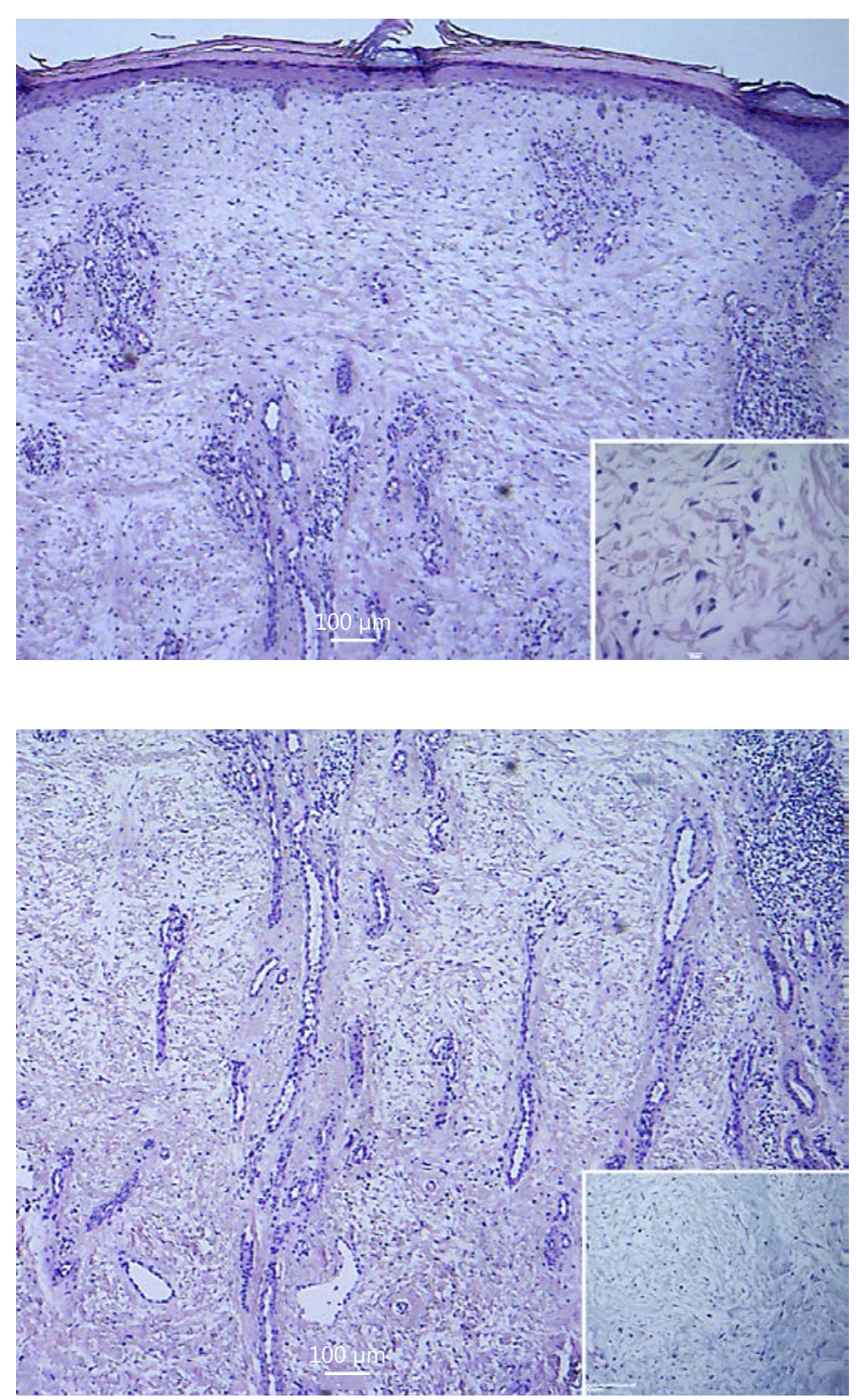

Fig. 4. H\&E (inset: Alcian Blue $\mathrm{pH}$ 2.5). Angioplasia with vertically running thickened capillary vessels. Moderate amount of mucin in the dermis (inset).

The pathogenesis of this rare condition has not been fully elucidated and, to the best of our knowledge, 22 cases have been reported in the English literature and are summarized in Table 1 [1-11]. Lymphatic stasis, stimulated by the obesity, seems to determine a local hypoxia leading to the accumulation of mucin [4]. This appears to be induced by the deposition in the interstice of plasmatic proteins due to a defect of the lymphatic drainage and the ischemia favored by a frequently associated venous insufficiency. A distinct histopathological picture for OALM, different from classic pretibial myxedema and from venous insufficiencyassociated dermal mucinosis, has been defined whose histopathological clues are (1) epidermal atrophy, (2) moderate amount of dermal mucin in the superficial dermis, (3) angioplasia made by vertically running vessels in the superficial and mid dermis, (4) increased stellate or linear fibroblasts; subepidermal blister can be occasionally seen [2]. On the contrary, pretibial myxedema shows an acanthotic epidermis with ortohyperkeratosis and diffuse striking mucin deposition throughout all the reticular dermis without evident angio- 
Table 1. Literature review of all cases of cutaneous pretibial mucinosis

\begin{tabular}{|c|c|c|c|c|c|}
\hline Patients & $\begin{array}{l}\text { Age, years/ } \\
\text { sex }\end{array}$ & Diagnosis & $\begin{array}{l}\text { Comor- } \\
\text { bidities }\end{array}$ & Follow-up & References \\
\hline 6 & $\begin{array}{l}38 / \mathrm{M} \\
77 / \mathrm{M} \\
66 / \mathrm{M} \\
49 / \mathrm{M} \\
70 / \mathrm{M} \\
80 / \mathrm{M}\end{array}$ & $\begin{array}{l}\text { Elephantiasis verrucosa nostra } \\
\text { Stasis dermatitis } \\
\text { Not specified } \\
\text { Pretibial myxedema } \\
\text { Pretibial myxedema } \\
\text { Elephantiasis verrucosa nostra }\end{array}$ & Obesity & None & $\begin{array}{l}\text { Somach et al. } \\
\text { (1993) [1] }\end{array}$ \\
\hline 1 & $44 / \mathrm{F}$ & Pretibial mucinosis & $\begin{array}{l}\text { Venous } \\
\text { insufficiency }\end{array}$ & None & $\begin{array}{l}\text { Kim et al. (2002) } \\
{[10]}\end{array}$ \\
\hline 3 & $\begin{array}{l}76 / \mathrm{M} \\
60 / \mathrm{F} \\
36 / \mathrm{M}\end{array}$ & OALM & Obesity & $\begin{array}{l}\text { 1. Pressure bandage therapy } \\
\text { 2. Pressure bandage therapy } \\
\text { effective only for the papules } \\
\text { 3. Woody plaque with } \\
\text { corticosteroids }\end{array}$ & $\begin{array}{l}\text { Tokuda et al. } \\
\text { (2006) [3] }\end{array}$ \\
\hline 5 & $\begin{array}{l}69 / \mathrm{M} \\
64 / \mathrm{F} \\
47 / \mathrm{F} \\
51 / \mathrm{F} \\
69 / \mathrm{F}\end{array}$ & OALM & Obesity & $\begin{array}{l}1 \& 5 \text { hypocaloric diet }(1,200 \mathrm{cal} / \\
\text { day) } \\
2 \& 5 \text { weight loss with clinical } \\
\text { improvement }\end{array}$ & $\begin{array}{l}\text { Rongioletti et al. } \\
\text { (2009) [2] }\end{array}$ \\
\hline 2 & $\begin{array}{l}73 / \mathrm{M} \\
61 / \mathrm{M}\end{array}$ & Dermal mucinosis & $\begin{array}{l}\text { Venous } \\
\text { insufficiency }\end{array}$ & $\begin{array}{l}\text { Triamcinolone laser, } \\
\text { topical steroids, } \\
\text { no improvement }\end{array}$ & $\begin{array}{l}\text { Pugashetti et al. } \\
\text { (2010) [9] }\end{array}$ \\
\hline 1 & $46 / \mathrm{M}$ & Pretibial mucinosis & None & $\begin{array}{l}\text { Triamcinolone acetonide } \\
\text { ointment under occlusion, } \\
\text { moderate improvement of } \\
\text { pruritus and slight improvement } \\
\text { in appearance }\end{array}$ & $\begin{array}{l}\text { Mir et al. (2011) } \\
{[8]}\end{array}$ \\
\hline 1 & $71 / \mathrm{M}$ & OALM & Obesity & $\begin{array}{l}\text { Compression hosiery, } \\
\text { weight loss, minimal } \\
\text { improvement }\end{array}$ & $\begin{array}{l}\text { Woolf et al. } \\
\text { (2014) [7] }\end{array}$ \\
\hline 1 & $78 / \mathrm{F}$ & OALM & Obesity & Suggested weight loss & $\begin{array}{l}\text { Brauns et al. } \\
\text { (2013) [5] }\end{array}$ \\
\hline 1 & $70 / \mathrm{F}$ & Pretibial mucinosis & Obesity & None & $\begin{array}{l}\text { Milman et al. } \\
\text { (2016) [4] }\end{array}$ \\
\hline 1 & $71 / \mathrm{F}$ & OALM & Obesity & $\begin{array}{l}\text { Pentoxyphyllin } 400 \mathrm{mg} \text {, } \\
\text { clobetasol } 17 \text {-propionate } 0.05 \% \\
\text { cream, triamcinolone acetonide } \\
\text { injections, weight loss suggested }\end{array}$ & $\begin{array}{l}\text { Karadag et al. } \\
(2014)[6]\end{array}$ \\
\hline 1 & $72 / \mathrm{F}$ & Pretibial mucinosis & $\begin{array}{l}\text { Venous } \\
\text { insufficiency }\end{array}$ & $\begin{array}{l}\mathrm{CO}_{2} \text { laser vaporization, } \\
\text { improvement }\end{array}$ & $\begin{array}{l}\text { Castiñeiras et al. } \\
\text { (2009) [11] }\end{array}$ \\
\hline 2 & $\begin{array}{l}72 / \mathrm{F} \\
76 / \mathrm{F}\end{array}$ & OALM & Obesity & $\begin{array}{l}\text { Low-calorie diet, } \\
\text { pressure improvement }\end{array}$ & Present paper \\
\hline
\end{tabular}

OALM, obesity-associated lymphedematous mucinosis.

plasia. Dermal mucinosis in the setting of chronic venous insufficiency is characterized by abundant dermal mucin deposition, a slight increase in small blood vessel density, slightly thickened vessel walls, and no inflammatory infiltrate.

OALM has usually a benign course but can cause a cosmetic disfigurement. Although there is no commonly accepted treatment, pressure bandage and diet restriction has been 
described as helpful. In our first case, gradual compression in association with a low-calorie diet obtained an improvement of the edematous stasis and the dermatologic condition.

\section{Statement of Ethics}

The study protocol has been approved by the local ethics committee and the subjects have given their informed consent to participate.

\section{Disclosure Statement}

The authors have no conflict of interest to declare.

\section{References}

$>1$ Somach SC, Helm TN, Lawlor KB, Bergfeld WF, Bass J: Pretibial mucin. Histologic patterns and clinical correlation. Arch Dermatol 1993;129:1152-1156.

-2 Rongioletti F, Donati P, Amantea A, et al: Obesity-associated lymphoedematous mucinosis. J Cutan Pathol 2009;36:1089-1094.

-3 Tokuda Y, Kawachi S, Murata H, Saida T: Chronic obesity lymphoedematous mucinosis: three cases of pretibial mucinosis in obese patients with pitting oedema. Br J Dermatol 2006;154:157-161.

4 Milman LM, Grill AB, Müller GP, De Ville D, Souza PRM: Pretibial mucinosis in an euthyroid patient. An Bras Dermatol 2016;91:100-102.

5 Brauns B, Mempel M, Schön MP, Seitz CS: Multiple slowly growing nodular lesions on the lower legs in a 78-year-old obese woman. Nodular obesity-associated lymphedematous mucinosis. JAMA Dermatol 2013; 149:867-868.

-6 Karadag AS, Ozlu E, Ozkanli S: Obesity-associated lymphedematous mucinosis. Indian J Dermatol Venereol Leprol 2014;80:456-457.

-7 Woolf RT, Ferrara G, Rongioletti F, Agarwal A, Wain EM, Stefanato CM: Unusual plaque and papules affecting the legs. Clin Exp Dermatol 2014;39:245-247.

8 Mir M, Jogi R, Rosen T: Pretibial mucinosis in a patient without Graves disease. Cutis 2011;88:300-302.

-9 Pugashetti R, Zedek DC, Seiverling EV, Rajendran P, Berger T: Dermal mucinosis as a sign of venous insufficiency. J Cutan Pathol 2010;37:292-296.

10 Kim KJ, Kim HH, Chang SE, Choi JH, Sung KJ, Moon KC, et al: A case of pretibial mucinosis without thyroid disease. J Dermatol 2002;29:383-385.

-11 Castiñeiras I, del Pozo J, Robles 0, Martínez-González C, Fernández-Torres R, Fonseca E: Euthyroid nodular pretibial mucinosis: palliative treatment with carbon dioxide laser. Dermatol Surg 2009;35:719-721. 